\title{
The Little Professor: Reflection on the Structure, Development and Evolution of the Adult in the Child
}

\author{
(C) 2019 Tânia Elizabeth Caetano Alves
}

This paper appeared originally in Portuguese as $O$ Pequeno Professor: Uma Reflexão Sobre a Estrutura, o Desenvolvimento e a Evolução do Adulto na Criança REBAT XXIII-OCTOBER 2014 PG 125-140 and is reproduced here by kind permission of UNAT-BRASIL - União Nacional de Analistas Transacionais - Brasil.

Where possible, quotations have been adjusted to reflect original English publications, particularly for TA publications which had been translated into Portuguese.

\section{Abstract}

According to the concept of the Life Script, developed by Eric Berne, the fate of each individual is sketched in the early years of life. The subdivision of Child Ego State, known as Adult in the Child or Little Professor, is responsible for decoding the world throughout intuition and analogical thought and, thus, in one way or another, having physical and emotional survival guaranteed. The purpose of this article is to qualify and recognise the Adult in the Child and its relevance in the construction of personality trait, by studying the anatomical, physiological and emotional scenario in which the Adult in the Child develops itself. The author suggests that the peculiar stamina and wisdom held in the Adult in the Child may be present in adult life in a positive manner, even if the events that structured it were dramatic.

\section{Key words}

Child Ego State, Adult in the Child, Little Professor, Generalised Representations, Evolutionary Development.

\section{Introduction}

"Look, the moon is flying" - David, 2 years

The observation of children has been a constant in my life for more than 30 years, initially as a paediatrician and later as a clinical transactional analyst. In all these years, both direct involvement with children and the Child ego states of adult patients has made my enchantment and admiration ever more consistent for the immense and courageous journey with which all human beings encounter their first years of life.

Like an alien on an unknown planet, the child at birth has the task of survival, to learn how to see, hear, walk and communicate in this new environment. Maybe they will not come across anything so complex and challenging again for the rest of their life. Therefore, an apparatus is required that not only can take care of the task but is able to constantly evolve throughout life.

The purpose of this work is to reflect, in terms of TA theory, on the subdivision of the Adult within the Child ego state, contextualising the scenario in which it develops and emphasising its task in the process of development.

\section{The Child's Brain}

According to Marta Pinheiro (2007) and Lewis and Wolkmar (1990), the development of the child's brain occurs as described below.

The brain begins to form between the third and fourth week of intrauterine life, in the so-called embryonic period, when the embryo measures approximately $0.5 \mathrm{~cm}$. The nervous system originates from one of the three embryonic layers, the ectoderm, which is the structure that is in contact with the external environment.

From a longitudinal thickening of this ectoderm, neural plaque arises, which later in its development 5th week - is rolled up, forming the so-called neural tube that remains inside the embryo, enveloped by the future epidermis that originates the primitive encephalic vesicles.

Neural stem cells, which are embryonic stem cells that specialise in the formation of the central nervous system, form precursor cells which, in turn, will form neurons and glia cells. The intense proliferation of these cells in this period, as well as the process of migration of the neuroblasts to the different regions of the nervous system, the selective aggregation of 
the young affine neurons, the differentiation and maturation of the neurons and the formation of the synapses, are building a situation such that, with 24 weeks of gestation, the baby's brain is almost complete, made up of billions of neurons and trillions of connections.

At birth, the brain weighs an average of 350 grams, has several structures that are still immature, and the process of myelination is still unfinished. This still immature and flexible brain is bombarded with an endless stream of stimuli from both the external environment and the inner environment through the perception of new sensations that are not yet capable of being filtered or blocked.

Therefore, the evolution of the brain is dynamic and biological, developing through the responses it gives to the environment. The child's brain has hundreds of trillions of connections, more synapses than it can use - $50 \%$ more than that of the average adult therefore, these experiences will determine which connections are left and which are lost.

Billions of neurons, trillions of connections, electrical and chemical energy, the child's brain, from birth or even before, is a system that is capable of learning from the external environment and that selects information which will be classified and recorded in the various neural networks. Each time the baby uses their senses as a way of perceiving their surroundings, a connection is formed. As these experiences repeat themselves, the brain connections intensify. We can say that the connections learned, or the paths that are recorded, build the way the child thinks, feels, speaks and does.

Eric Berne, based on the work of Penfield (1952), and Federn (1952), defined ego states as "coherent systems of thought and feeling manifested by corresponding patterns of behaviour" (Berne, 1972, p.11; 1988, p.25). Noting that patients could be seen moving from one mental state and one pattern of behaviour to another, Berne inferred the existence of three psychic organs: the Exteropsyche, Neopsyche and Archeopsyche, which manifest phenomenologically and operationally as the three ego states of Parent, Adult and Child (Berne, 1961).

In the same book, Transactional Analysis in Psychotherapy, Berne suggested the hypothesis that infantile ego states, existing as relics in the adult, could be re-lived through various circumstances that involved, one way or another, brain stimulation like "dreams, hypnosis, psychosis, pharmacological intoxicants, and direct electrical stimulation of the temporal cortex ... can exhibit spontaneous activity in the waking state as well." (Berne, 1961, p.31).
Several transactional analysts, including Jenni Hine and James Allen, have sought to understand where and how, neurologically speaking, the psychic organs manifest themselves as ego states.

Jenni Hine, both in her article Mind Structure and Ego States (Hine, 1997, 2003-4) and in the later publication Brain Structures and Ego States (Hine, 2005) proposes several considerations, many based on Joseph LeDoux's (2002) work on ego, self and mind, relating them to the Parent, Adult, and Child systems. Several of these considerations are especially interesting for this current reflection on the Child ego state:

About Self - Hine understands the formation of the self as, "our identity, our self, the essence of who we are ... arises bit by bit from the unique neural connections that our own participation in life experiences lead us to construct." (Hine, 2005, p.40).

In her study, Hine presents several considerations about self-understanding, highlighting the neurological nature of the self, and quotes LeDoux (2002) as stating: "Given the importance of synaptic transmission in brain function, it should practically be a truism to say that the self is synaptic. What else can it be?" (p.2)" (Hine, 2005, p.40).

Another important consideration is the participation of memory in the composition of the self, both explicit and implicit memory, both building our identity and not just the contents of which we are aware.

On Generalised Representations - Hine describes a generalised representation as: "A GR can be understood as a cluster of perceptions that has acquired mental meaning because it has converged over time and through repetition to have become interconnected ... activated whenever a familiar signal stimulates any of their component parts" (Hine, 2005, p.42).)

According to Hine, a generalised representation of an event - meaning the occurrence of innumerable types of physical or mental experiences - is the knowledge and reactions to this knowledge that are constructed by the perceptions of different occurrences of similar facts until this becomes the expected stereotype for future occurrences of the same experiment. Hine also says that a generalised representation is constituted of a pattern of mental or neural connections that, over time, have been reinforced until they become available for activation through the appearance of a familiar stimulus.

Here is an example observed by the author illustrating this statement: $A$, before he was 2 years old, owned and knew a plush toy zebra like Zeze [http://keyframestudios.co.uk/Zeze/]. He could also recognise this same figure, with two eyes and dark 
and clear stripes, when it appeared in books or other papers. The Zeze event was repeated in many ways, in the many experiences he had playing with the stuffed animal and with its images that were always named in the same way. One day, looking at a pine cabinet, he pointed and said Zeze. And yes, there was, in the drawing formed by the veins of the wood, a black dot and the outline of a body outlined with light and dark lines: obviously Zeze. A generalised representation.

On ego states, self-states, and generalised representations - for Hine, each ego state reflects a slightly different self-awareness from the others, so we have a self-state or a Parent awareness of self, an Adult awareness-of self, and a Child awareness of self. For the author, these self-states or ego states are networks of generalised representations, and although each of them has slight differences in their awareness of self and personality, this does not preclude the existence of a global identity or personality.

It is important to emphasise that when we think about ego states with this understanding, it is implied that we are referring to brain areas, even though the areas related to each of these self-states or ego states are scattered in the brain and not concentrated in a single region, as follows: "The functioning of one of our PAC self-states is, therefore, the totality of a particular state of mental activation in response to signals from people around us or to internal signals from within us, formed and condensed over time as complex systems of interconnected GRs" (Hine, 2005, p.43).

For Hine, the different manifestations of ego states are because they were formed using different neural pathways that activate different patterns of neural networks when receiving external or internal stimuli.

\section{Formation of Child Ego State}

Between birth and five years of age, more or less, through the various experiences and trials of the person at this time, the Child ego state and its substructures are forming. Just as each ego state has its own characteristics, we can also, through Second and Third Order Structural Analysis, identify the subdivisions of the ego states, each with its own structure and content. The Adult in the Child is one of these substructures and, to better reflect on its constitution, it is necessary to contextualise it as part of the Child ego state.

Berne describes the Child ego state as "a set of feelings, attitudes and behaviour patterns which are relics of the individual's own childhood" (Berne, 1961, p.77; 1985, p.72). Some years later, Berne referred to the Child that "each person carries within a little boy or little girl, who feels, thinks, acts, talks, and responds just the way he or she did when he or she was a child of a certain age. " (Berne, 1972, p.12; 1988, p.25). According to him, this Child must be understood because, besides accompanying the person throughout life, it will also constitute the most precious part of personality.

Although we do not know exactly when the awareness of existence begins, we know that, even before birth, the baby is able to perceive stimuli coming from the environment, both internal and external, although in this period the child experiences himself and the environment as one. According to Schiff and Contributors (1975), the most decisive events during the intrauterine period are those that occur with the parents and how this is reflected in the physiology and health of the pregnant woman and, consequently, the baby. This is because, in addition to the experience of their own physical development, the first perceptions of rhythms occur in this stage. The unborn child already perceives "the rhythms of their own body and also those of their mother's body." (p.24-35)

According to Hine (2004), the formation of generalised representations begins well before birth, arising from the experience of bodily sensations and continues to be constructed, more actively, in the first years of life, through early emotional experiences and interactions the infant has with those who provide care. At birth, the baby's vision is like a blurred photograph and the still immature brain cannot handle everything it sees. Due to the immaturity of nerve cells in the retina and cerebral cortex, visual acuity at birth is very low. New-borns are able to focus attention on strong contrast stimuli, seeing blurred shapes such as black and white and grayscale images.

This progresses so that at one month the baby's attention will be more directed towards the extremities and contours of the head and face, beginning at two to three months to observe the eyes and mouth, and at about five months, being able to perceive the face as a whole. Colour is perceived at the same time and visual acuity is estimated to evolve from very low in two-week-old infants to reach similarity with adult acuity at age five (Lewis and Wolkmar, 1990). Babies listen at birth and their auditory acuity improves rapidly in the first days of life, continuing to improve during the first two years. Within a week of birth, they can recognise the voice of their mother and at birth are able to identify the source of a sound. As for the senses of the palate, smell and touch, it is known that at birth new-borns discriminate sweet tastes as well as the other three basic tastes - salt, bitter and acid, and also possess good olfactory capacity and a developing tactile capacity. 
Although it is estimated that only $40 \%$ of the hippocampus is mature at birth, infants soon recognise and are able to remember the mother's voice, face, smell and taste although initially the memory is short-term. With a month, a child can remember a mobile for about 24 hours, while at five or six months, they can remember for several weeks an object seen for a few minutes.

The fact that the baby is able to see, smell, hear and remember, even if not in a fully developed way, creates the possibility of experiencing non-rhythmic experiences and giving meaning to them. According to Schiff et al (1975), the perception of the mother's eyes, smell and smile is one of these non-rhythmic experiences that signal the beginning of symbiosis. This is the period of formation of Child in the Child (C1), composed of subdivisions $\mathrm{CO}, \mathrm{AO}$ and PO.

Jenni Hine (1997) refers to $C 1$ as a specialised subsystem, very sensitive to internal stimulation, which forms at birth, or even in intrauterine life, through the creation of generalised representations of physical and emotional stimuli coming from the internal and external environment. C0 (Child Zero) is understood as the biological child, with the instinctive part and the reflex reactions to stimuli that are proper to humans. $\mathrm{CO}$ is who we are when we are born, rudimentary instrumentalised beings for survival and sociability - the emerging self.

Not only are we born capable of seeing, hearing, sucking and grasping in a highly specific way, but also of bonding ourselves in our first hours of life (Lewis and Wolkmar, 1990).

According to Allen and Allen (2005) precocious ego states (C1, $A 1$ and $P 1)$ develop basically in the right brain in the Sympathetic Vegetative Nervous System [nowadays called the autonomic nervous system (ANS)], which would explain the characteristics of excitement and joy of the child and analogical thinking. The substructure designated as $\mathrm{A} 0$ begins to develop around the time of birth. According to Schiff et al (1975), the onset of A0 (Adult Zero) would occur at the time that recognition of certain family stimuli begins, which results in a sufficiently significant somatic response by $\mathrm{C} 0$ to be recalled.

Note the similarity to the concept of generalised representations mentioned above. This substructure of $\mathrm{C} 1$ - A 0 will be responsible for learning through experience. Between two and four months, the baby begins to realise that there is a relationship between the inner sensation of hunger, the act of crying and sucking and the response of the external environment to it. The association of these situations will allow the child to create a relationship between these actions and the final result of the experience, which will be the ingestion of food.
This behavioural bridge - Hunger - Crying - Food - at this moment mediated by the Adult in the Child, still in formation, is, according to Schiff et al (1975), the beginning of learning to think.

The beginning of the development of PO (Parent Zero) occurs when the baby begins to develop adaptive responses to the environment and represents the incorporation of the Parent that relates to the most basic needs of the child (Schiff, 1977). Messages related to PO are usually somatic and nonverbal.

The forming structures of $\mathrm{C} 1(\mathrm{CO}, \mathrm{A} 0$ and $\mathrm{P} 0)$ are the most primitive organised functions and, as they are elaborated and differentiated, will foster personality development. When the child is between five and six months old, the $\mathrm{C} 1$ substructure is formed and the two other substructures of the Child ego state begin to develop.

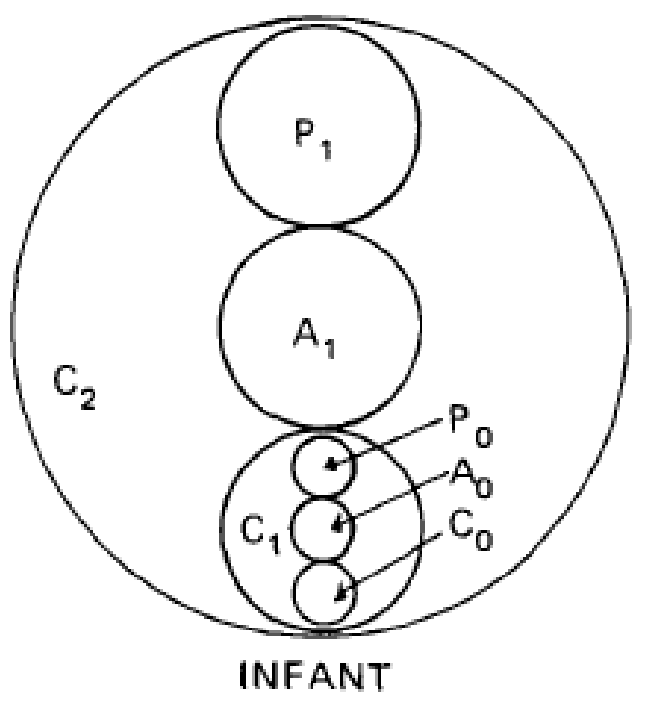

Figure 1: Development of the Child Ego State (Schiff, 1977, p.312)

P1- Parent in the Child- Although there are different opinions about when the P1 structure begins to develop, several authors who have dedicated themselves to the study of evolutionary development point to the period between 12 months and 3 years for the beginning of the formation of P1.

Schöfield (1992), who made a comparative study of child development in transactional analysis, cites Levin-Landheer (1982), Mavis Klein (1980), and Schiff et al (1975) among these authors. It is in this period, between 1 and 3 years, that the child is usually trained to control the sphincters and it is also the period in which the parental figures become more restrictive, NO being a word much used by both the child and the parents.

According to Schiff, at this time the child begins to conceptualise and the Parent, which is being 
developed, is a fantasy of an external father who can be either negative or positive. This fantasised external parent, when incorporated, will serve as a repressive parental figure that will allow the child to be conditioned.

Berne (1972) called the Parent in the Child the Electrode. According to him, when the Parent in the head of Jeder - a character Berne created to designate any man - presses the button, Jeder's P1 jumps, whether its other parts want to or not.

Steiner (1974) refers to this subdivision of the Child as the Witch Mother or Ogre, and explains the name by saying that this Witch Mother has the function of forcing people to do things they do not want to do. According to Steiner, the Parent in the Child (P1) and the Parent (P2) present some characteristics in common such as the fact that both are parental structures, with parental behaviours learned from external figures. However, while Parent in the Child may behave in a seemingly protective manner, the real support and protection comes from P2. The power of subdivision $\mathrm{P} 1$ will be directed toward oppressive attitudes and conditioning.

According to Berne, the great difference between a trained animal and a domesticated animal is that "a trained animal will obey his master's voice when he hears it out loud; a tamed one doesn't need to hear the sound, because it carries it around in its brain" (Berne, 1972. p.64). We can close this topic by saying that the child is the most domesticated animal of all.

Another way of looking at this structure (P1) is the one proposed by Hargaden and Sills (2002). According to those authors, the child, when experiencing a negative experience related to the external environment, may perceive themself as unable to deal with the feelings arising from it. These feelings, not being processed properly, can be experienced as intolerable to the child. In order to manage them, the child keeps them as if they are separated from them, pushed into the P1 structure.

The usefulness of this is that, in this way, the child can coexist with feelings that would otherwise be threatening, making $\mathrm{P} 1$ therefore a space to contain introjections and denied parts of the self.

\section{A1- Adult in the Child}

Berne referred to Adult in Child as a keen and perceptive scholar of human nature whom he called Little Professor.

There are several opinions regarding the age at which the development of the Adult in the Child begins, and most of the authors who refer to this issue point to six months as the age from which the A1 is structured (Schofield, 1992). In the period of 6 to 12 months there is a significant change in the emotional meaning of relationships. Until then, many different people could meet the baby's need for attention. In this new phase, with the onset of individuation, the child perceives the mother as the other, a separate structure. It is the height of awareness of symbiosis. Between six and nine months the child expresses clearly and intensely that people other than the mother disturb them. The baby can already remember the mother's face and perceive the differences when comparing her memory with other faces. The Adult in the Child is involved in this internalization of the mother figure or adult caregiver, so that the memory of the mother's face can be used not only for comparison but to retain the image in the absence of the mother.

Hine (1997) refers to $A 1$ as a pre-logical cognitive system very sensitive to the suggestion of urgency in both internal stimuli, such as hunger, and external stimuli, such as the perception of signs that the mother is about to leave the environment where the child is. The Little Professor presupposes purposeful learning experience and much of early life learning is related to survival issues. The baby needs someone to take care of it to survive. Therefore, A1's intuitive attention to urgency guides the child's attention to important stimuli, such as the mother moving away, by trying to learn ways to keep the separation from happening. Most babies cry when they see themselves separated from their mothers and welcome them on their return with clear signs of pleasure, although they can also utter complaining sounds amidst the shrieks and laughter.

Hargaden and Sills (2002) refer to A1 as representing the child's attempts to understand themself, others and the world. This understanding is based on the experiences of $\mathrm{C} 1$ and the patterns of later relationships. According to those authors, A1 is the basis of the child's personality and presents in two ways, $A 1$ positive and $A 1$ negative. The positive $A 1$ is the self-image that is maintained by the messages of Counterscript, being the sense of OKness related to the retention of the bond with the other and to the successful adaptation of the child to these messages. The negative $\mathrm{A} 1$ is the appropriation, by the child, of those moments when she feels not $\mathrm{OK}$ and experiences negative injunctions. If the child's needs are met and her perception of herself is positive, these two $A 1$ facets integrate, providing the child with a sense of OKness about herself.

Berne (1972) referred to the analogical way of thinking of the Little Professor as Martian thought. According to him, the Martian language translates the words to their real meaning in terms of results and allows the child to discover what their parents 
really want. The task of the Adult in the Child is to intuit and think Martian in order to seek ways for survival. And they will do this as a small child can do - using intuition and magic.

It is important that we visualise the person we are talking about. Energy is directed towards the development of the $\mathrm{A} 1$ from about six months to about three or four years old. We are speaking, therefore, of a person who covers their eyes so that others will not see them, who knows how to read the subtle signs emitted by the adults who are important to them, and who, after reflecting and questioning, concludes that sea water originates from the spit of fish, is learning to speak and sing and control the sphincters, and who just learned to walk.

Berne (1972) suggested that the adult structure with which the child unravels the world at this time, the Little Professor, serves as a balance between two forms of behaviour, the Adapted Child and the Natural Child, deciding at every moment what kind of behaviour to use or repress in order to remain bonded to parents or caregivers. The behaviour of the Adapted Child is to avoid behaviours that are not adapted, while the behaviour of the Natural Child is spontaneous and expressive, dangerous for the A1, who seeks social adaptation. The defence mechanisms that the Little Professor uses to shape the Adapted Child and to contain the Natural Child are necessarily fanciful and limited.

Abreu and Lima (1988) addressed this theme and, according to, the Little Professor, through adverse environmental situations, organises powerful defence mechanisms, in a magical and fanciful way to hide the Free Child, the 'self' itself and shapes the Adapted Child as more adaptable and less authentic. According to this contribution, the Little Professor, when feeling threatened, structures and models without limitation, and represses and silences the Free Child's inclinations.

According to Lima, this uncontrolled defensive behaviour of the $A 1$, in the face of the inhospitable environment, can become dangerous, as this defensive resistance creates a Sphinx child, cunning, destructive, enigmatic and perverse, whose purpose of existence is the repression of the Free Child. The A1 is smart, intuitive and devoid of ethics, fighting for survival in the way that seems most effective. The kind of thinking that the Child in the Adult does, which fascinates all of us, means that we find most small children to be cute and charming and does not reveal the inner process that occurs in the early years of life; which is not funny but instead is dramatic.

English (1969), in describing the Episcript or the Hot Potato Game, also refers to this determination of the
Little Professor who, being instinctively committed to life, resorts to magical thinking, at the same time, to meet its priorities of obtaining parental strokes and defending itself from injunctions. But, however agile and firm the Adult in the Child may be, it cannot resist the force of the injunctions. To solve this, it sets up the episcript - "a secret plot based on the magic assumption that tragedy to the self can be avoided by passing it on to a sacrificial object, a victim or scapegoat" (English, 1969, p.77; 2005, p.306). ).

Also according to English, there is a belief, a secret plan that the A1 adheres to or builds, which is to magically manipulate the script and pass it on to another person, in an attempt to avoid the final hamartic script ending. Thus, C2, the full Child ego state, is formed by these three vigorous and intense components, C1, A1 and P1.

And what is the fate of the Little Professor and the Child ego state as a whole, after childhood? Berne took a position on the Child ego state - C2 - in two different ways. In one of them, he saw C2 as an archaic and pathological ego state, composed of fixed content, resulting from related trauma, for example with unmet needs (Berne, 1961). In another, he saw the Child as the most valuable part of the individual's personality, which would accompany him throughout his life (Berne, 1972).

Transactional Analysts involved with this topic have positioned themselves one way or another according to their understanding of the issue. Stewart (2001) notes that these positions stem from the way transactional analysis professionals define Parent, Adult, and Child. If the Child is understood only as fixed material and unresolved issues of childhood, it will be seen as something from which we must rid ourselves of its pathological potential. He goes on to say that if instead the Child is understood to be all of our experience of the past, containing both the elements of script and autonomous childlike material, then we may perceive it as the source of energy and intuition in adult life. Other transactional analysts have a similar understanding, among them Clarkson (1988) and Goulding \& Goulding (1978).

Blackstone (1993, trans 2005) states that: "In my opinion, any person's Child ego state(s) is inherently healthy. The more trauma someone dealt with in childhood, the healthier his or her C2 is because its structure and function show how the child successfully overcame significant hurdles in order to have a present." (1993, p.218; 2005, p.255). Hargaden and Sills (2002) suggest that when there was a sufficiently healthy childhood, C2 covers in its internal organisation the constituent elements of the earliest ego states, integrated so that the self can be 
perceived as cohesive. Moreover, "... that the Child, although certainly being limited by the imperfections of parenting and environment, sits securely as the reliable core of the Adult" (p.27).

\section{Final considerations}

Humans are like patchwork quilts in their more or less successful attempt to tailor their good and bad experiences in the pursuit of a sense of self. From before birth our perceptions of the inner and outer environment are organised into generalised representations of the world that are activated when signs of the environment stimulate one of its parts. Ego states, such as Child, can be understood as networks of generalised representation networks, and therefore neural routes with an immense number of neurons and synaptic connections that can be activated by meaningful family stimuli.

The precocious ego states - C1, A1 and P1 - with their various contents coming from interaction with the environment, organise themselves with the pressing purpose of relating to one another, parents or adult caregivers, learning to decode what the parental figures really want and how to develop in the midst of child-caregiver interaction. The A1 subdivision, the Little Professor, is especially committed to survival, having to figure out the best way to maintain the bond with parental figures while trying to get rid of the injunctions given by these same figures. A1 is a naive and astute 'adult' who seeks to change reality to meet basic needs, with resources being intuition, Martian thinking and fantasy. While the child seeks to appropriate and metabolise the whole of its experiences, it encounters adverse situations in which the result of harmful and inappropriate interactions is defensively fixed and isolated, and this material is hardly accessible for change.

After childhood, the Child ego state, C2, formed by recording the events of a person's childhood, with their peculiar perceptions, basic decisions and conclusions, can be activated through networks of generalised representations that respond to bodily and emotional signals and also to transactional stimuli of figures that evoke parental figures.

If we can bear in mind that when children, armed with instinct, desire, and a handful of "slightly warped ego units (a set of pennies from a poor mold." (Berne, 1961 , p.54; 1985, p.50), dare to sketch their future, perhaps we may feel more empowered to deal with the memories of these realities.

Finally, we can only reaffirm the desire that, as transactional analysts, we can recover and help others recover the energy and wisdom of the Child, so that we become adults who believe in magic.
"Fleas jump so much because they also have fleas" (Mário Quintana, 1983, when 77 years old)

\section{Author}

Tânia Elizabeth Caetano Alves MD, is a psychotherapist who holds Transactional Analysis Clinical Certification from UNAT-BRASIL. She can be contacted on taniaea@terra.com.br

\section{References}

Allen, James \& Allen, Barbara. (2005) Therapeutic

Journey: Practice and Life. Oakland: TA Press

Berne, Eric (1961) Transactional Analysis in

Psychotherapy New York: Grove Press

Berne, Eric. (1972) What Do You Say After You Say Hello? New York: Grove Press

Berne, Eric. (1985) Análise Transacional em Psicoterapia. [Transactional Analysis in Psychotherapy] São Paulo:

Summus. (quotations taken from this version)

Berne, Eric. (1988) O que você diz depois de dizer olá? [What do you say after you say Hello?] São Paulo: Nobel (quotations taken from this version)

Blackstone, Peg (1993) The Dynamic Child: Integration of second order structure, object relations, and self psychology Transactional Analysis Journal. 23(4), 216-234 https://doi.org/10.1177/036215379302300406

Blackstone, Peg. (2005) 'A Criança Dinâmica: Integração da Estrutura de Segunda Ordem, Relações Objetais e psicologia do Self. In: UNAT-BRASIL. Prêmios Eric Berne 1971-1997. Porto Alegre: Suliani Editografia Ltda. 251281.

Clarkson, Petrūska (1988) Ego State Dilemmas of Abused Children Transactional Analysis Journal. 18(2), 85-93. https://doi.org/10.1177/036215378801800203

English, Fanita (1969) Episcript and the "Hot Potato" Game Transactional Analysis Bulletin. 8(32), 77-82.

English, Fanita. (2005) Episcript ou o Jogo da Batata Quente. In: BRASIL, Unat-. Prêmios Eric Berne 19711997. Porto Alegre: Suliani Editografia Ltda. 306-312.

Federn, Paul (1952) Ego Psychology and the Psychoses New York: Basic Books https://doi.org/10.1037/10571-000

Goulding, Robert \& Goulding, Mary (1978) The Power is in the Patient San Francisco: TA Press

Hargaden, Helena \& Sills, Charlotte. (2002) Transactional Analysis: A Relational Perspective. London: Routledge

Hine, Jenni. (1997) Mind Structure and Ego States. Transactional Analysis Journal. 27(4), 278-289. https://doi.org/10.1177/036215379702700407

Hine, Jenni. (2003/2004) Estruturas Cerebrais e Estados de Ego. Revista Brasileira de Análise Transacional. Ano XIII,v.1/ Ano XIV,v.1 59-80. 
Hine, Jenni (2005) Brain Structures and Ego States Transactional Analysis Journal, 35(1), 40-51. https://doi.org/10.1177/036215370503500106

Klein, Mavis (1980) Thoughts and Feelings: A Functional Description of Health, Pathology, Diagnosis and Cure Transactional Analysis Journal. 10(2), 96-100. https://doi.org/10.1177/036215378001000203

LeDoux, 1. (2002). Synaptic self: How our brains become who we are. New York: Penguin Putnam.

Levin-Landheer, Pamela (1982) The Cycle of

Development Transactional Analysis Journal. 12(2), 129139. https://doi.org/10.1177/036215378201200207

Lewis, Melvin \& Wolkmar, Fred. (1993) Aspectos Clínicos do Desenvolvimento na Infância e Adolescência. Porto Alegre: Artes Médicas

Lima, Michelle de Abreu e. A Criança (1988) Esfinge: impasse de $3^{\circ}$ grau. Revista Brasileira de Análise Transacional. 1(1), 18-35.

Penfield, Wilder (1952) Memory Mechanisms Archives of Neurology \& Psychiatry. 67, 178-198.

https://doi.org/10.1001/archneurpsyc.1952.023201400460 $\underline{05}$
Pinheiro, Marta.(2007) Fundamentos de NeuropsicologiaO desenvolvimento cerebral da criança. Vita Et Sanitas. 1(1), 34-47.

Quintana, Mário.(1983) Lili inventa o mundo. [Lily Invents the World] Porto Alegre: Mercado Aberto

Schiff, Jacqui \& Contributors (1975), Cathexis Reader: Transactional Analysis Treatment of Psychosis New York: Harper \& Row Publishers Inc

Schiff, Shea. (1977) Personality development and Symbiosis. Transactional Analysis Journal. 7(4), 310-316. https://doi.org/10.1177/036215377700700407

Schöfield, David. (1992) A comparative TA view of child development. In Clarkson, P. Transactional Analysis Psychotherapy: An Integrated Approach, New York: Routledge Appendix A. 311-319

Steiner, Claude (1976). Os Papéis Que Vivemos Na Vida. São Cristovão: Artenova

Stewart, lan (2001) Ego States and the Theory of The Theory: The Strange Case of the Little Professor Transactional Analysis Journal. 31(2) 133-147. https://doi.org/10.1177/036215370103100209 